\title{
Anomalous negative excursion of carbon isotope in organic carbon after the last Paleoproterozoic glaciation in North America
}

\author{
Yasuhito Sekine \\ Department of Complexity Science and Engineering, University of Tokyo, Kashiwa, Chiba 277-8561, Japan \\ (sekine@k.u-tokyo.ac.jp)
}

Eiichi Tajika

Department of Earth and Planetary Science, University of Tokyo, Bunkyo, Tokyo 113-0033, Japan

Naohiko Ohkouchi and Nanako O. Ogawa

Institute of Biogeosciences, Japan Agency for Marine-Earth Science and Technology, Yokosuka, Kanagawa 237-0061, Japan

\section{Kazuhisa Goto}

Disaster Control Research Center, Tohoku University, Sendai, Miyagi 980-8579, Japan

Now at Planetary Exploration Research Center, Chiba Institute of Technology, Tsudanuma, Japan

\section{Ryuji Tada and Shinji Yamamoto}

Department of Earth and Planetary Science, University of Tokyo, Bunkyo, Tokyo 113-0033, Japan

\section{Joseph L. Kirschvink}

Division of Geological and Planetary Sciences, California Institute of Technology, Pasadena, California 91125, USA

[1] Early Paleoproterozoic time (2.5-2.0 Ga) spanned a critical phase in Earth's history, characterized by repeated glaciations and an increase in atmospheric oxygen (the Great Oxidation Event (GOE)). Following the last and most intense glaciation of this period, marine carbonates record a large positive excursion of $\delta^{13} \mathrm{C}$ value (termed the "Lomagundi event") between about 2.2 and $2.1 \mathrm{Ga}$ coinciding with the global appearances of red beds and sulfates, which suggest an accumulation of high levels of atmospheric oxygen. Here we report the discovery of large negative excursions of $\delta^{13} \mathrm{C}$ in organic matter (down to $-55 \%$ ) from quartzose sandstones (of the Marquette Range and the Huronian Supergroups, North America) intermediate in age between the last Paleoproterozoic glaciation and the possible onset of the Lomagundi event. The negative excursion is concomitant with the appearance of intensely weathered quartzose sandstones, which may represent hot and humid conditions. There are some interpretations that potentially explain the negative excursions: (1) redeposition of older ${ }^{13} \mathrm{C}$-depleted kerogen, (2) later post-depositional infiltration of oil, (3) active methane productions by methanogens in shallow-marine environments, or (4) dissociation of methane hydrate. If the latter two were the case, they would provide clues for understanding the environmental change connecting the intense glaciation and an increase in oxygen. 
Components: 6100 words, 3 figures.

Keywords: Great Oxidation Event; carbon isotope; climate change; glaciation; Paleoproterozoic; atmospheric evolution.

Index Terms: 0325 Atmospheric Composition and Structure: Evolution of the atmosphere (1610, 8125); 1055 Geochemistry: Organic and biogenic geochemistry; 1051 Geochemistry: Sedimentary geochemistry.

Received 4 May 2010; Revised 28 June 2010; Accepted 1 July 2010; Published 21 August 2010.

Sekine, Y., E. Tajika, N. Ohkouchi, N. O. Ogawa, K. Goto, R. Tada, S. Yamamoto, and J. L. Kirschvink (2010), Anomalous negative excursion of carbon isotope in organic carbon after the last Paleoproterozoic glaciation in North America, Geochem. Geophys. Geosyst., 11, Q08019, doi:10.1029/2010GC003210.

\section{Introduction}

[2] Evidence of repeated glaciations during the Paleoproterozoic has been reported from North America, Fennoscandia, South Africa, and Western Australia [e.g., Ojakangas, 1988; Marmo et al., 1988; Young, 1991; Kohonen and Marmo, 1992; Kirschvink et al., 2000; Ojakangas et al., 2001a, 2001b; Bekker et al., 2001, 2004; Young, 2004]. Following the glaciations, a large positive excursion of $\delta^{13} \mathrm{C}$ in carbonate (termed the "Lomagundi event") coincided with the global appearance of terrestrial red beds and sulfates in sedimentary sequences of ages $2.2-2.1$ Ga [e.g., Karhu and Holland, 1996; Bekker et al., 2006; Holland, 2006]. It suggests elevated burial rate of organic carbon in sediments, and thus rapid accumulation of oxygen in the atmosphere [Karhu and Holland, 1996]. Alternatively, the Lomagundi event is interpreted as indicating that methanogenesis would have been pushed to deep levels in the sediments in response to the transition to oxidizing surface environments during the Great Oxidation Event (GOE) [Hayes and Waldbauer, 2006]. Although previous studies have proposed for the surface environmental change during the Lomagundi event, the mechanism connecting the last Paleoproterozoic glacial event and the Lomagundi event has been poorly understood. Given that variations in the $\delta^{13} \mathrm{C}$ values of carbonate $\left(\delta^{13} \mathrm{C}_{\text {carb }}\right)$ and organic carbon $\left(\delta^{13} \mathrm{C}_{\mathrm{org}}\right)$ in sedimentary rocks are useful for reconstructing variations in the biogeochemical carbon cycle, continuous $\delta^{13} \mathrm{C}$ records that span the interval from the termination of the last Paleoproterozoic glaciation (c.a., $2.22 \mathrm{Ga}$ ) to the Lomagundi event would provide key information in understanding the linkage between the glaciation and the GOE.

[3] Paleoproterozoic glaciogenic deposits have been found at several sites in North America, including a diamictite-bearing unit in the Marquette Range
Supergroup, Michigan, USA [Ojakangas et al., 2001b; Bekker et al., 2006], and three discrete units in the Huronian Supergroup, Ontario, Canada [e.g., Young, 1991, 2004] (Figure 1). The Chocolay Group of the Marquette Range Supergroup consists of diamictite (Enchantment Lake Formation), sandstone (Mesnard Formation), and carbonate (Kona Dolomite) in ascending stratigraphic order (Figure 1b). The depositional age of the Enchantment Lake Formation has been constrained to between 2.29 and $2.13 \mathrm{Ga}$ [Vallini et al., 2006]. Positive $\delta^{13} \mathrm{C}_{\text {carb }}$ excursions that may represent the onset of the Lomagundi event have been observed in the Kona Dolomite [Bekker et al., 2006]. Thus, the Chocolay Group may be a key sequence that preserves a biogeochemical record over the period from the last Paleoproterozoic glaciation to the Lomagundi event. The Chocolay Group has been correlated, on lithostratigraphic grounds, with the Cobalt Group of the Huronian Supergroup [Ojakangas, 1988; Ojakangas et al., 2001b; Young, 2004; Bekker et al., 2006]. The Cobalt Group contains diamictite and argillite (Coleman and Firstbrook Members of Gowganda Formation, respectively), sandstone (Lorrain Formation), and mudstone with thin carbonate layers with high $\delta^{13} \mathrm{C}_{\mathrm{carb}}$ (Gordon Lake Formation) [Bekker et al., 2006] (Figure 1b). The widespread nature of glaciogenic deposits in the Gowganda Formation and possible equivalents in North America, Fennoscandia, and South Africa suggest the occurrence of a global-scale glacial event during the Paleoproterozoic [Kohonen and Marmo, 1992; Evans et al., 1997; Ojakangas et al., 2001a, 2001b; Young, 2004; Bekker et al., 2004, 2006].

[4] In this study, we discuss carbon isotopic variations in the sedimentary sequences of the Chocolay and Cobalt groups that span the interval from the last Paleoproterozoic glaciation to the Lomagundi event with the aim of reconstructing the biogeochemical cycle in the glacial aftermath. We 


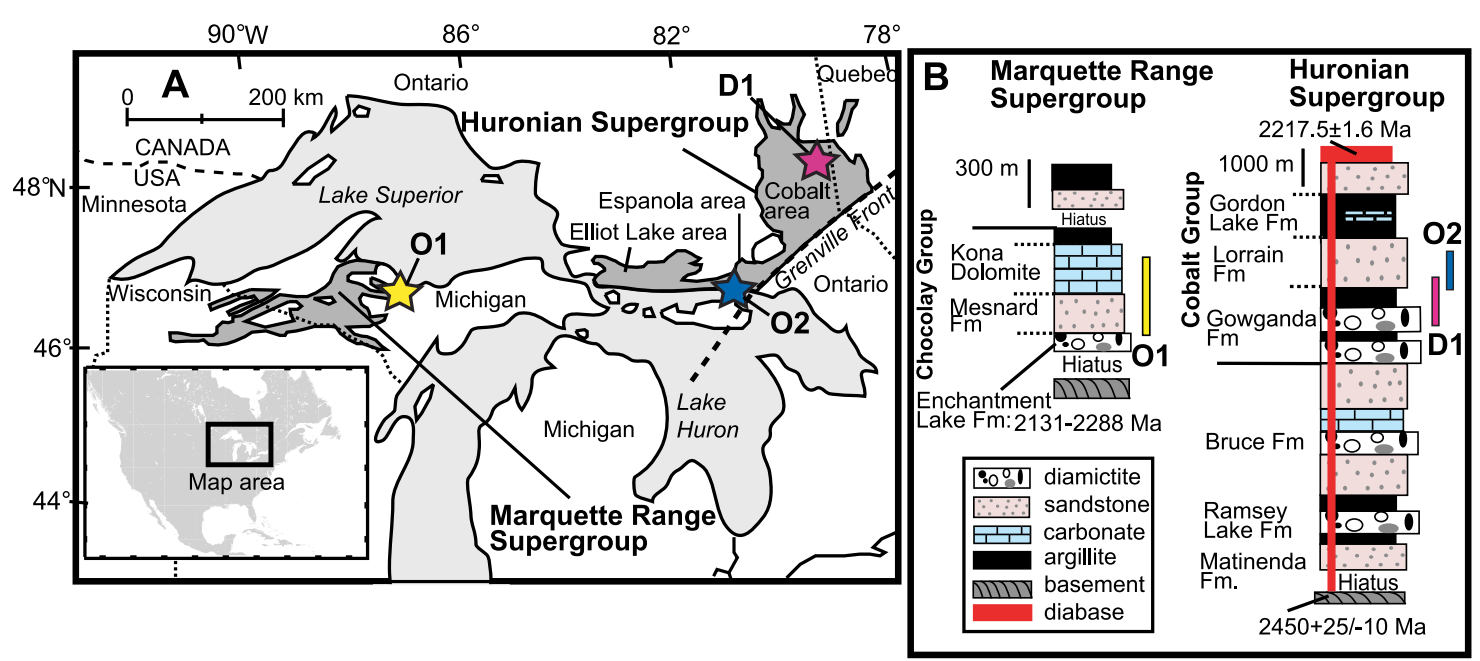

Figure 1. Distribution and stratigraphy of the Marquette Range and Huronian Supergroups in North America. (a) The yellow star (O1) represents the sampling locality of the Chocolay Group of the Marquette Range Supergroup. The blue star (O2) and red star (D1) represent sampling localities of the Cobalt Group of the Huronian Supergroup. (b) Yellow, blue, and red vertical bars represent the stratigraphic intervals sampled at sites O1, O2, and D1, respectively. The age constraints for the Huronian Supergroup are from Young et al. [2001] and Bekker et al. [2006, and references therein]. The age constraint for the Enchantment Lake Formation is given by Vallini et al. [2006].

analyze sedimentary organic matter because carbonates are not preserved within and immediately above the diamictites. Because $\delta^{13} \mathrm{C}_{\text {org }}$ values tend to be more strongly influenced by local conditions relative to $\delta^{13} \mathrm{C}_{\text {carb }}$, we investigate $\delta^{13} \mathrm{C}_{\text {org }}$ variations to compare the Chocolay and Cobalt groups as a means of obtaining $\delta^{13} \mathrm{C}_{\text {org }}$ variations representative at least in basin scale rather than just a local signal. Based on these $\delta^{13} \mathrm{C}_{\text {org }}$ variations, we discuss the climatic recovery path from the glacial event, biogeochemical cycles, and its linkage with the increase in atmospheric oxygen.

\section{Geological Setting}

[5] The Chocolay Group of the Marquette Range Supergroup crops out along the southern shore of Lake Superior [e.g., Ojakangas et al., 2001b; Young, 2004; Bekker et al., 2006] (Figure 1a). The basal units of the Chocolay Group include a diamictitebearing member of the Enchantment Lake Formation that unconformably overlies Archean basement. Gray sandstone of the Enchantment Lake Formation contains dropstones up to cobble size that are typical of ancient glacial deposits [Ojakangas et al., 2001b]. The Mesnard Formation is composed of cross-bedded quartzose sandstone which deposited in a shallow-marine environment [Ojakangas et al., 2001b]. The Kona Dolomite conformably overlies the Mesnard Formation with intercalations of thin mudstones occurring in the uppermost part of the Mesnard Formation. The lower part of the Kona Dolomite is more argillaceous, while the upper part is predominantly dolomitic and consists of upwardshallowing cycles of stromatolitic dolomites capped by mudstones and sandstones [Bekker et al., 2006].

[6] The Huronian Supergroup crops out along the north shore of Lake Huron (Figure 1a) [e.g., Young, 1991; Young et al., 2001]. The upper Huronian Supergroup (starting with the Gowganda Formation) is considered as a passive margin succession dominated by siliciclastic sediments [Young et al., 2001; Young, 2004]. The lower Gowganda Formation (the Coleman Member) consists of a diamictitebearing unit, while the upper Gowganda Formation (the Firstbrook Member) consists of a laminated mudstone and siltstone of shallow-marine origin. The Gowganda Formation is conformably overlain by a sandstone unit of the Lorrain Formation. The intensely weathered quartzose sandstone in the middle and upper Lorrain Formation has been interpreted as representing the climatic recovery in the aftermath of the Gowganda glaciation [Long et al., 1999]. The presence of abundant detrital hematite are found in the middle Lorrain Formation, suggesting presence of some free oxygen in the atmosphere [Young et al., 2001], although possibility of contribution of ironoxidizing photosynthetic organisms are not excluded. The Lorrain Formation is overlain by the Gordon Lake Formation which is composed mainly of sili- 
ceous mudstone, siltstone, and sandstone with occasional intercalation of carbonate layers [Bekker et al., 2006].

\section{Sampling and Analyses}

[7] Samples of the Chocolay Group were collected from a section of outcrop (O1 in Figure 1) along the route that contains a record of the Enchantment Lake, Mesnard, and Kona formations. Our sampling area of the Chocolay Group was located in the northeastern part of the group near the city of Marquette at latitude from $46^{\circ} 30^{\prime} 60^{\prime \prime}$ to $46^{\circ} 31^{\prime} 10^{\prime \prime}$ north and longitude from $87^{\circ} 25^{\prime} 15^{\prime \prime}$ to $87^{\circ} 25^{\prime} 40^{\prime \prime}$ west (Figure S1 in Text S1). ${ }^{1}$ At the sampling area, the Enchantment Lake Formation appears to be overlain by the Mesnard Formation with a gradual contact, as described in the previous study [Gair, 1981]; however, there is still some debate on the nature of this contact because an unconformity is suggested to exist between the Enchantment Lake Formation and the overlying Mesnard Formation [Ojakangas et al., 2001b]. We collected 8 samples from the Enchantment Lake Formation, 27 samples from the Mesnard Formation, and 33 samples from the Kona Dolomite.

[8] Samples of the Gowganda and Lorrain formations of the Huronian Supergroup were collected from a drillcore retrieved from locality D1 in the Cobalt area (Figure 1), and from an outcrop at locality $\mathrm{O} 2$ in the Espanola area (Figure 1). Samples through the Gowganda to Lorrain formations were collected continuously from an outcrop in the southwest part of the Espanola area (called Whitefish Falls) at about latitude from $46^{\circ} 06^{\prime} 55^{\prime \prime}$ to $46^{\circ} 07^{\prime} 35^{\prime \prime}$ north and longitude from $81^{\circ} 43^{\prime} 40^{\prime \prime}$ to $81^{\circ} 44^{\prime} 00^{\prime \prime}$ west (Figure S2 in Text S1) and from a drillcore (CO0338; stored at Ontario Geological Survey) at latitude $48^{\circ} 02^{\prime}$ north and longitude $80^{\circ} 21^{\prime}$ west. A detailed description of the outcrop of the Huronian Supergroup (O1) was reported in other studies [Young, 1991; Young et al., 2004]. We collected 13 samples at the lower to upper part of the Lorrain Formation from the outcrop. Drillcore samples span the Coleman Member of the Gowganda Formation through the lower part of the Lorrain Formation. A detailed description of the drillcore is given by Rainbird and Donaldson [1988]. From the drillcore, we collected 8 samples from the Coleman

\footnotetext{
${ }^{1}$ Auxiliary materials are available in the HTML. doi:10.1029/ 2010GC003210.
}

Member, 15 samples from the Firstbrook Member, and 19 samples from the Lorrain Formation.

[9] To remove potential contaminants, the surfaces of the rock samples were cut off with a diamondimpregnated saw blade. Then, the samples were cleaned and crushed with a ball mill. We pulverized the matrix of diamictite samples. For the determination of isotopic composition of organic carbon, the powder samples were treated with $6 \mathrm{M}$ hydrochloric acid $(\mathrm{HCl})$ for 2 days. Then, they were washed with distilled water several times to remove calcium salt and dried in an oven.

[10] To characterize the organic materials in the rock samples, we conducted further treatments for some rock samples after $\mathrm{HCl}$ treatment: (i) dichloromethane (DCM) treatment and (ii) hydrofluoric acid (HF) and $\mathrm{HCl}$ treatment and subsequent DCM treatment. For DCM treatment, we added about $4 \mathrm{ml}$ of DCM into the residues after the $\mathrm{HCl}$ treatment and washed them in an ultrasonic bath for $30 \mathrm{~min}$ to remove soluble organic materials, such as bitumen. After centrifugal separation of the samples, the supernatant DCM was removed. The DCM treatment as described above was repeated twice. For $\mathrm{HF} / \mathrm{HCl}$ treatment, we added about $10 \mathrm{ml}$ of $10 \% \mathrm{HF}$ and $\mathrm{HCl}$ to the samples for 1 day to dissolve silicate minerals. The residues were rinsed several times with $\mathrm{HCl}$ to reduce fluorides and then three times with Milli-Q water. The subsequent DCM treatment was performed for the air-dried residues after $\mathrm{HF} / \mathrm{HCl}$ treatment to remove hydrocarbons trapped in fluid inclusions in silicate minerals.

[11] Measurements of $\delta^{13} \mathrm{C}_{\text {org }}$ were performed by a modified online system of Thermo Finnigan Delta Plus XP isotope-ratio mass spectrometry coupled to a Flash EA1112 elemental analyzer (EA/IRMS) through a ConFlo III interface at JAMSTEC [Ohkouchi et al., 2005]. About $30 \mathrm{mg}$ of the powder samples were transferred to precleaned tin capsules and then introduced into the EA/IRMS system. Total organic carbon content in the samples was determined by calibrated ion currents of $\mathrm{m} / \mathrm{z} 44$ in isotope ratio mass spectrometry. Carbon isotopic compositions were expressed as conventional $\delta$ notation against VPDB standard; $\delta^{13} \mathrm{C}=$ $\left({ }^{13} \mathrm{R}_{\text {sample }}{ }^{13} \mathrm{R}_{\text {standard }}-1\right) \times 1000$, where ${ }^{13} \mathrm{R}$ is ${ }^{13} \mathrm{C} /{ }^{12} \mathrm{C}$ ratio. The EA/IRMS system was modified to improve sensitivity [Ogawa et al., 2010]. In this EA/IRMS system, peak height of $\mathrm{m} / \mathrm{z} 44$ chromatogram for blank samples (without samples in tin capsules) was generally $70-80 \mathrm{mV}$ (originated 
probably from graphite in tin capsule) with isotopic composition of around $-21 \%$, whereas those of samples range from 2000 to over $7000 \mathrm{mV}$. Some of these samples have very low total organic carbon (TOC) contents; however, because the amount of carbon dioxide in a system blank used for our elemental analysis was much lower than that within the samples, the system blank does not generate a significant change in the measured $\delta^{13} \mathrm{C}_{\text {org }}$ values. Analytical error ( $95 \%$ probability) was estimated to be about $0.2 \%$ based on the repeated measurements of authentic and laboratory standards [Ogawa et al., 2010].

[12] Major chemical and mineralogical compositions of the bulk rock samples were analyzed with standard X-ray fluorescence (XRF) technologies (AXIOS, PANalytical) and a X-ray Diffractmeter (XRD) (X'PERT-PRO, PANalytical), respectively, at Univ. of Tokyo. Quartz contents in the samples (wt $\%$ ) were obtained with a XRD internal standard method using silicon powder with a correlation for the effect of the crystallinity of quartz on its peak height based on Nagashima [2005]. Relative abundances of plagioclase in samples (counts/g) were obtained using XRD signal counts at the peak of plagioclase normalized by sample weights.

[13] For $\delta^{13} \mathrm{C}_{\text {carb }}$ analyses, $\mathrm{CO}_{2}$ was extracted from $\sim 0.1-1 \mathrm{~g}$ of powdered carbonate rock by reaction with $\mathrm{H}_{3} \mathrm{PO}_{4}$ at $25^{\circ} \mathrm{C}$ for 2 days in sealed vessels. The extracted $\mathrm{CO}_{2}$ was analyzed with a Finnigan MAT 252 isotope ratio mass spectrometer at Univ. of Tokyo. Analytical data of $\delta^{13} \mathrm{C}_{\mathrm{org}}, \delta^{13} \mathrm{C}_{\text {carb }}$, and chemical and mineralogical compositions are available in Tables S1 and S2 in Text S1, respectively.

\section{Results and Discussion}

[14] In the Chocolay Group, we found an initial negative excursion in $\delta^{13} \mathrm{C}_{\text {org }}$ record down to about $-40 \%$ (Figure 2a), starting 1-2 $\mathrm{m}$ below the top of the Enchantment Lake Diamictite and persisting throughout most of the Mesnard Formation. At $\sim 70-110 \mathrm{~m}$ above the contact between the Enchantment Lake and Mesnard Formations, $\delta^{13} \mathrm{C}_{\text {org }}$ values show a brief drop to $\sim-55 \%$ before gradually recovering to $-20 \%$ o toward the upper part of the Mesnard Formation. In the Kona Dolomite, we also observe positive $\delta^{13} \mathrm{C}_{\text {carb }}$ values ( $\sim-9 \%)$, as previously reported by Bekker et al. [2006]. Averaged fractionation between organic and carbonate carbon in Kona Dolomite is $29 \%$, ranging from 23.4 to $36.6 \%$. These values seem to be consistent with primary producers using the Calvin Cycle for autotrophic carbon fixation, supporting the hypothesis that a primary positive carbon excursion is responsible for the Lomagundi event.

[15] There are three possibilities for the chemical form of the organic matters in the rock samples from the Mesnard Formation showing the negative $\delta^{13} \mathrm{C}_{\text {org }}$ value: soluble bitumen, hydrocarbons trapped in fluid inclusions in silicate minerals, and insoluble complex organic molecules, kerogen. Figure 2 indicates that $\delta^{13} \mathrm{C}_{\text {org }}$ values after (i) DCM treatment (removing bitumen) and (ii) $\mathrm{HF} / \mathrm{HCl}$ dissociation and the subsequent DCM treatment (removing hydrocarbons trapped in fluid inclusions) also show extremely negative values (ranging from -44 to $-55 \%$ ). These results strongly suggest that the ${ }^{13} \mathrm{C}$-depleted signatures predominately represent values of kerogen in the rock samples.

[16] To investigate the reproducibility of the extremely negative $\delta^{13} \mathrm{C}_{\text {org }}$, we conducted repeated measurements of $\delta^{13} \mathrm{C}_{\text {org }}$ for one rock sample at $100 \mathrm{~m}$ above the contact (see the data for Figure 2 and Table S1 in Text S1: the results of MQ9 and MQ9(1) are obtained using one powdered sample, and those of MQ9, MQ9(1), MQ9-, MQ9-(1), and MQ9+ are obtained using three different powdered samples from one rock sample). All these samples have the extremely negative $\delta^{13} \mathrm{C}_{\mathrm{org}}$ values (from $-49 \%$ to $-56 \%$ ). According to the $\delta^{13} \mathrm{C}_{\text {org }}$ measurements, the variation in $\delta^{13} \mathrm{C}_{\text {org }}$ from the rock sample is obtained to be $\sim 3 \%$ o $(1 \sigma)$. Although the variation is larger than the analytical error $(\sim 0.2 \%)$, this is significantly smaller than the amplitude of the measured $\delta^{13} \mathrm{C}_{\text {org }}$ excursions. Furthermore, the samples of MQ300, MQ202.5, and MQ202.6 (see Table S1 in Text S1) were collected in the different sampling point (but the same horizons in the stratigraphy) at the distance of $\sim 300 \mathrm{~m}$ from that of the other samples in the Marquette Range Supergroup. The similar negative $\delta^{13} \mathrm{C}_{\text {org }}$ values from these samples suggest that very local alterations or analytical artifacts are not the case for the measured negative $\delta^{13} \mathrm{C}_{\text {org }}$.

[17] Similar $\delta^{13} \mathrm{C}_{\text {org }}$ variations are observed in both sections in the Huronian Supergroup (Figure 2b). Initial values of around $-25 \%$ within the Firstbrook Member decrease to around $-40 \%$ in the lower part of the Lorrain Formation. In the upper Lorrain Formation, $\delta^{13} \mathrm{C}_{\text {org }}$ values drop again to $-55 \%$. The similar nature of the $\delta^{13} \mathrm{C}_{\text {org }}$ trends 
A. Chocolay Group (Marquette Range Supergroup)

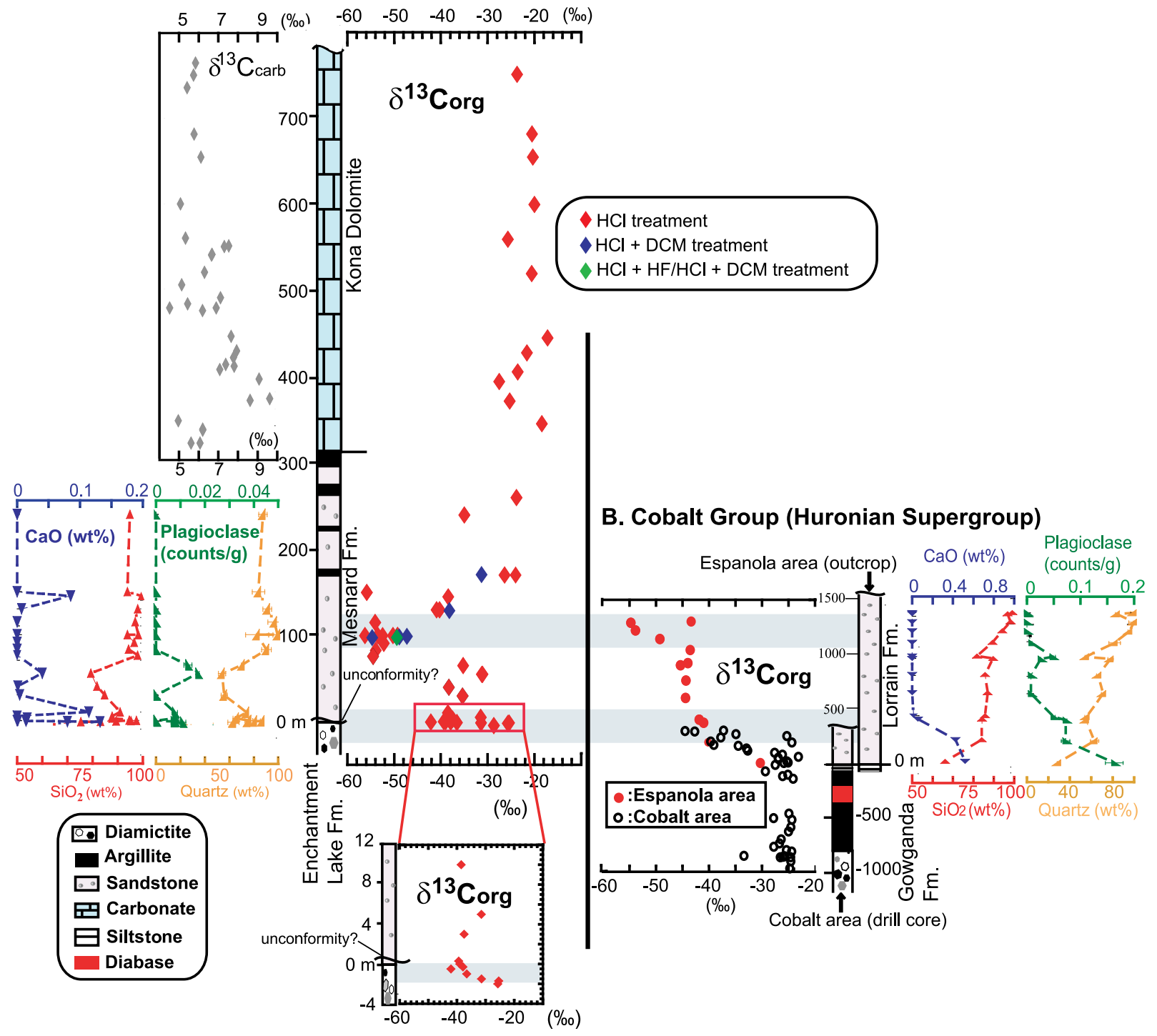

Figure 2. Variations in $\delta^{13} \mathrm{C}_{\text {org }}$ and $\delta^{13} \mathrm{C}_{\text {carb }}$ values and bulk mineralogical and chemical data for the Chocolay and Cobalt groups. (a) Chocolay Group, showing a range in $\delta^{13} \mathrm{C}_{\text {org }}$ values from $-57 \%$ to $-17 \%$. (b) Cobalt Group, showing a range in $\delta^{13} \mathrm{C}_{\mathrm{org}}$ values from $-55 \%$ to $-25 \%$. In both the drillcore and outcrop samples, negative $\delta^{13} \mathrm{C}_{\mathrm{org}}$ shifts are recorded in the lower Lorrain Formation. The bulk mineralogical and chemical compositions $\mathrm{SiO}_{2}, \mathrm{CaO}$, quartz, and plagioclase) of sandstones and the sandy matrixes within diamictites are shown along the columnar sections for both groups. Light blue lines indicate the horizons of the two negative $\delta^{13} \mathrm{C}_{\mathrm{org}}$ excursions.

recorded in the Chocolay and Cobalt groups supports the lithostratigraphical correlation of the diamictite units between the groups [Ojakangas et al., 2001b; Young, 2004; Bekker et al., 2006].

[18] We also note that in all of the analyzed sections, the large, negative $\delta^{13} \mathrm{C}_{\text {org }}$ excursions are coincident with unusual, intensely weathered quartzose sandstones (Figure 2). The bulk chemical and mineralogical compositions of sedimentary rocks in the Mesnard and Lorrain formations show that $\mathrm{Ca}$,
$\mathrm{Na}$, and $\mathrm{K}$ (unaltered plagioclases) are more highly depleted in samples with lower $\delta^{13} \mathrm{C}_{\text {org }}$ values; such samples also have extremely high bulk $\mathrm{SiO}_{2}$ contents and high proportions of quartz grains $\left(\mathrm{SiO}_{2}>90 \mathrm{wt} \%\right)$. In the upper Mesnard Formation, the high $\mathrm{SiO}_{2}$ and quartz contents persist after the recovery of the negative $\delta^{13} \mathrm{C}_{\text {org }}$ excursion. These quartzose sandstones, along with possible equivalents in Fennoscandia [Ojakangas et al., 2001a], represent the products of strong chemical weathering under hot, humid climate, suggesting a global 


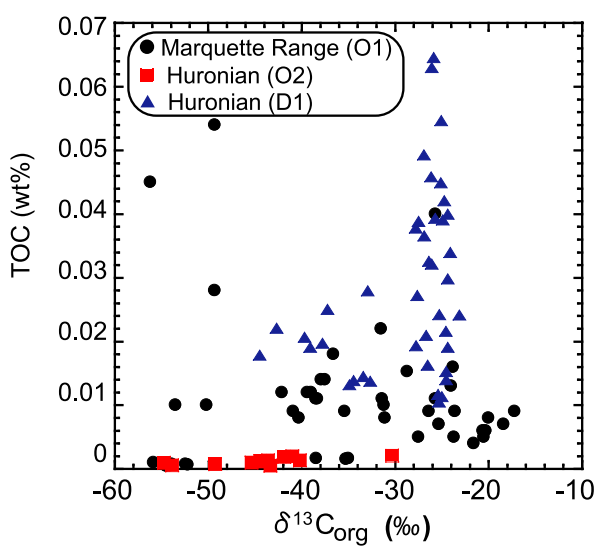

Figure 3. Relationship between total organic carbon (TOC) content and $\delta^{13} \mathrm{C}_{\text {org }}$ values of our samples. Black circles, red squares, and blue triangles represent the results from the outcrop in the Marquette Range Supergroup (O1 in Figure 1) and from the outcrop $(\mathrm{O} 2$ in Figure 1) and the drill core (D1 in Figure 1) in the Huronian Supergroup.

change to greenhouse conditions [Young, 1991; Ojakangas et al., 2001b; Bekker et al., 2006]. Thus, the co-occurrence of negative $\delta^{13} \mathrm{C}_{\text {org }}$ excursions with intervals of quartzose sandstones indicates the existence of an additional post-glacial climatic factor that connects the two sets of observations.

\section{Potential Interpretations}

[19] There are several interpretations that potentially explain the large negative $\delta^{13} \mathrm{C}_{\text {org }}$ values (down to $-55 \%$ ) in our samples. Values of $\delta^{13} \mathrm{C}_{\text {org }}$ can be affected by post-depositional metamorphism and thermal alteration. Since our samples contain organic carbon as small as $0.0005-0.153 \%$, the isotopic record is prone to be altered by these processes. Because of low TOC contents in the samples, it is difficult to characterize the form of ${ }^{13} \mathrm{C}$-depleted kerogen in the samples for constraining the timing of formation of it [e.g., Rasmussen et al., 2008]. However, in contrast to the depletion in ${ }^{13} \mathrm{C}$ observed in the present study, the post-depositional metamorphism and thermal alteration are suggested to result in ${ }^{13} \mathrm{C}$ enrichment in organic matter via re-equilibration with carbonate and thermal degradation [Hayes et al., 1983]. Considering the magnitude of carbon isotope fractionation associated with $\mathrm{CO}_{2}$ assimilation by Rubisco ( - -30\%), $\delta^{13} \mathrm{C}_{\text {org }}$ excursions down to -40 to $-55 \%$ cannot be explained solely in terms of the physiological aspect of photoautotrophic organisms [Eigenbrode and Freeman, 2006]. Thus, methanogenesis and/or methanotrophic activities would attribute to the negative $\delta^{13} \mathrm{C}_{\mathrm{org}}$ anomalies. At this stage, it is difficult to conclude which interpretation is correct. Nevertheless, given the exceptionally large negative anomalies and significance of the $\delta^{13} \mathrm{C}_{\text {org }}$ variations in sedimentary rocks during the Paleoproterozoic, it is worth discussing the possible interpretations and the issues to be solved for future studies.

\subsection{Detrital Components}

[20] Considering the negative $\delta^{13} \mathrm{C}_{\text {org }}$ values ( -40 to $-55 \%$ ) in our samples, it is conceivable that specific local processes, such as deposition of migrated oil trapped in fluid inclusions in silicate minerals, might contribute to the observed negative $\delta^{13} \mathrm{C}_{\mathrm{org}}$ excursions. In fact, oil-bearing fluid inclusions in the Matinenda Formation of the Huronian Supergroup [Dutkiewicz et al., 2006] are most likely source of migrated oil. However, the negative $\delta^{13} \mathrm{C}_{\text {org }}$ value after the $\mathrm{HF} / \mathrm{HCl}$ and subsequent DCM treatments does not support that the isotopic signatures mainly represent values of migrated oil trapped in fluid inclusions. The Late Archean Superior Province could have been a source area of detrital components for sedimentary rocks of the Huronian Supergroup [McLennan et al., 2000]. Thus, the carbon isotope results could simply represent eroded and redeposited kerogen from organic-rich shales of the Superior Province that also show highly negative $\delta^{13} \mathrm{C}_{\text {org }}$ values [Schoell and Wellmer, 1981]. If redeposition of ${ }^{13} \mathrm{C}$-depleted kerogen from the Archean shales causes the negative $\delta^{13} \mathrm{C}_{\text {org }}$ excursions in our samples, the observed negative $\delta^{13} \mathrm{C}_{\mathrm{org}}$ values could not represent biological/geological events at the time of deposition. However, the cooccurrence of the negative $\delta^{13} \mathrm{C}_{\text {org }}$ shifts at three geographically separated localities in North America (i.e., the Cobalt and Espanola areas in the Huronian Supergroup and the Marquette area in the Marquette Range Supergroup) may not be explained by such a contribution of very local redeposition of organic carbon.

\subsection{Post-depositional Contamination}

[21] The observed negative $\delta^{13} \mathrm{C}_{\text {org }}$ values could be explained by much later post-depositional infiltration of ${ }^{13} \mathrm{C}$-depleted oil generated from younger methanotrophic/methanogenic biomass into pores of the quartzose sandstones. However, few literatures have reported $\delta^{13} \mathrm{C}_{\text {org }}$ values of oil as low as $-55 \%$ (a typical $\delta^{13} \mathrm{C}_{\text {org }}$ value of kerogen in oil is about -25 to $-30 \%$ [e.g., Clayton, 1991]). In addition, the infiltration of oil would typically 
result in a linear relationship between TOC content and $\delta^{13} \mathrm{C}_{\text {org }}$ value of the samples [e.g., Bekker and Kaufman, 2007]. Nevertheless, our results of no clear correlation between them (Figure 3) imply that there may be no mixing trend between the deposited organic matters and post-depositional infiltration of oil.

[22] The samples with ${ }^{13} \mathrm{C}$-depleted organic matter are quartzose sandstones that have very low TOC contents making analysis challenging; nevertheless, a very low $\mathrm{CO}_{2}$ amount for the blank sample in our EA/IRMS analyses and its isotopic composition (about -21\%) (see Ogawa et al. [2010] and sections 3 and 4 of the present paper) strongly suggest that the measured $\delta^{13} \mathrm{C}_{\text {org }}$ values are little affected by analytical artifacts.

\subsection{Enhanced Methanotrophy in the Glacial Aftermath}

[23] Considering the similar nature of negative $\delta^{13} \mathrm{C}_{\text {org }}$ values of ca. $2.8 \mathrm{Ga}$ [Hayes, 1994; Eigenbrode and Freeman, 2006], our results potentially represent a basin-scale, active anaerobic or aerobic methanotrophy induced by the enhanced biogeochemical cycling of methane. According to these models [Hayes, 1994; Bekker and Kaufman, 2007], the isotopic signal of methanotrophy appears most strongly around the redox boundary between anoxic deep ocean and oxidizing shallow marine in redox stratified ocean. Given that the Lorrain and Menard formations are fluvial-deltaic and shallowmarine deposits, respectively [Ojakangas et al., 2001b; Young, 1991; Bekker et al., 2006], the strong isotopic signal of methanotrophy in these sedimentary sequences could suggest methane-rich sedimentary conditions in shallow-water environments in the aftermath of the last Huronian glaciation. The extremely negative $\delta^{13} \mathrm{C}_{\mathrm{org}}$ values suggest that the contribution of methanogenesis and methanotrophic carbon is dominant for the organic matters in the sediments (i.e., the flux of planktonic organic carbon was almost consumed, and most of the preserved organic matters in the sediments are related to methane oxidation).

[24] Although the magnitude of negative $\delta^{13} \mathrm{C}_{\text {org }}$ shifts is different, such an enhancement of methane production by methanogens and subsequent oxidative recycling by methanotrophs in shallowwater environments is proposed to have occurred under greenhouse conditions in the aftermath of the oldest Huronian glaciation $\left(\delta^{13} \mathrm{C}_{\text {org }}\right.$ down to $\sim-40 \%$ ) [Bekker and Kaufman, 2007]. Multiple lines of evidence suggest that the atmospheric oxygen levels have increased dramatically during the repeated Paleoproterozoic glaciations (Figure 1b) [e.g., Young et al., 2001; Bekker et al., 2004; Papineau et al., 2007]. Despite of the difference in the redox conditions in the environments (such as the concentrations of marine sulfate and atmospheric oxygen) between the oldest and last Paleoproterozoic glaciations, the negative shifts in $\delta^{13} \mathrm{C}_{\text {org }}$ appear repeatedly in the aftermath of the glaciations. If our finding of negative $\delta^{13} \mathrm{C}_{\text {org }}$ also represents the enhancement of methanogenic activity, climatic factor (i.e., a hot and humid condition in the glacial aftermath) would be a key to enhance methanogenic activity, pushing the redox boundary shallower in the ocean.

\subsection{Dissociation of Methane Hydrate}

[25] Given the negative $\delta^{13} \mathrm{C}_{\text {org }}$ shifts coinciding with the occurrence of intensely weathered quartzose sandstones overlying glacial diamictites, the analyzed geochemical data may represent the large-scale dissociation or multiple sources of local dissociation of methane hydrates in the aftermath of the last Paleoproterozoic glaciation. The release of methane supplies ${ }^{13} \mathrm{C}$-depleted carbon into the atmosphere-ocean system, leading to warm climate due to the greenhouse effect of methane and carbon dioxide produced photochemically from methane. The elevated air temperature enhances the chemical weathering of continental crusts, which would, in turn, provide continental phosphorus to the ocean. It subsequently leads to a cyanobacterial bloom, resulting in initiating the Lomagundi event and accelerating the GOE. Although an anomalously large amount of methane would be required for explaining the $\delta^{13} \mathrm{C}_{\text {org }}$ shifts, it is likely that the accumulation of methane hydrates during largescale Paleoproterozoic glaciation far exceeded the size of the modern hydrate pool. During the last Paleoproterozoic glaciation, low oxygen and sulfate concentrations in the Paleoproterozoic deep oceans would have significantly enhanced methane abundance in marine sediments [Pavlov et al., 2003].

[26] There are unsolved problems on the hypothesis of large-scale methane hydrate dissociation; that is, the timing of the dissociation of methane hydrate after the glaciation and lack of strong negative $\delta^{13} \mathrm{C}$ values in coetaneous carbonates so far. Although we observed a similar $\delta^{13} \mathrm{C}_{\text {org }}$ trend recorded in the Chocolay and Cobalt groups, the negative $\delta^{13} \mathrm{C}_{\text {org }}$ shift begins at the uppermost of diamictite layer (the Enchantment Lake Formation) in the Chocolay 
group, whereas it begins at the boundary between the deltaic sediments (the Firstbrook Member) following immediately on the glaciation and the extremely weathered quartzose sandstone (the Lorrain Formation) in the Cobalt group.

\section{Summary}

[27] We found one of the largest negative shifts in $\delta^{13} \mathrm{C}_{\text {org }}$ record (down to $-55 \%$ ) in Earth's history from quartzose sandstones of both the Marquette Range and Huronian supergroups intermediate in age between the last Paleoproterozoic glaciation and the possible onset of the Lomagundi event. Several scenarios potentially explain the observed negative excursions in $\delta^{13} \mathrm{C}_{\text {org. }}$. Although it is difficult at this stage to rule out the possibilities of redeposition of older ${ }^{13} \mathrm{C}$-depleted kerogen, the similarity of negative $\delta^{13} \mathrm{C}_{\text {org }}$ shifts with the co-appearance of intensely weathered quartzose sandstones recorded in the separated sampling areas in North America can also imply a massive supply of ${ }^{13} \mathrm{C}$-depleted methane through biological (an active methane production by methanogens) and/or geological processes (dissociation of methane hydrate) in the aftermath of the last Paleoproterozoic glaciation.

\section{Acknowledgments}

[28] Y.S. thanks J. Marmo and Yukio Isozaki for fruitful discussions; H. Sakuma, Yuko Isozaki, H. Hasegawa, K. Shiroya, H. Yoshida, and H. Nakayama for technical help with XRF and XRD analyses; and T. Hirai, S. Kimura, M. Hailstone, and A. Pace for helping to collect rock samples. This study is partly supported by Grants in Aid from Japan Society for the Promotion of Science (14403004 and 18340128), the 21 century COE Program at Department of Earth and Planetary Science, University of Tokyo, the Mitsubishi foundation, and the Agouron Institute.

\section{References}

Bekker, A., and A. J. Kaufman (2007), Oxidative forcing of global climatic change: A biogeochemical record across the oldest Paleoproterozoic ice age in North America, Earth Planet. Sci. Lett., 258, 486-499, doi:10.1016/j.eps1.2007. 04.009.

Bekker, A., A. J. Kaufman, J. A. Karhu, N. J. Beukes, Q. D. Swart, L. L. Coetzee, and K. A. Eriksson (2001), Chemostratigraphy of the Paleoproterozoic Duitschland formation, South Africa: Implications for coupled climate change and carbon cycling, Am. J. Sci., 301, 261-285, doi:10.2475/ajs.301.3.261.

Bekker, A., H. D. Holland, P.-L. Wang, D. Rumble III, H. J. Stein, J. L. Hannah, L. L. Coetzee, and N. J. Beukes
(2004), Dating the rise of atmospheric oxygen, Nature, 427, 117-120, doi:10.1038/nature02260.

Bekker, A., J. A. Karhu, and A. J. Kaufman (2006), Carbon isotope record for the onset of the Lomagundi carbon isotope excursion in the Great Lakes area, North America, Precambrian Res., 148, 145-180, doi:10.1016/j.precamres.2006.03. 008.

Clayton, C. J. (1991), Effect of maturity on carbon isotope ratios of oils and condensates, Org. Geochem., 17, 887-899, doi:10.1016/0146-6380(91)90030-N.

Dutkiewicz, A., H. Volk, S. C. George, J. Ridley, and R. Buick (2006), Biomarkers from Huronian oil-bearing fluid inclusions: An uncontaminated record of life before the Great Oxidation Event, Geology, 34, 437-440, doi:10.1130/ G22360.1.

Eigenbrode, J. L., and K. H. Freeman (2006), Late Archean rise of aerobic microbial ecosystems, Proc. Natl. Acad. Sci. U. S. A., 103, 15,759-15,764, doi:10.1073/pnas.0607540103.

Evans, D. A., N. J. Beukes, and J. L. Kirschvink (1997), Lowlatitude glaciation in the Paleoproterozoic era, Nature, 386, 262-266, doi:10.1038/386262a0.

Gair, J. E. (1981), Lower Proterozoic glacial deposits of northern Michigan, USA, in Earth's Pre-Pleistocene Glacial Record, edited by M. J. Hambrey and W. B. Harland, pp. 803-806, Cambridge Univ. Press, Cambridge, U. K.

Hayes, J. M. (1994), Global methanotrophy at the ArcheanProterozoic transition, in Early Life on Earth, vol. 84, edited by S. Bengtson, pp. 220-236, Columbia Univ. Press, New York

Hayes, J. M., and J. R. Waldbauer (2006), The carbon cycle and associated redox processes through time, Philos. Trans. R. Soc. B, 361, 931-950, doi:10.1098/rstb.2006.1840.

Hayes, J. M., I. R. Kaplan, and K. W. Wedeking (1983), Precambrian organic geochemistry, preservation of the record, in The Earth's Earliest Biosphere: Its Origin and Evolution, edited by J. W. Schopf, pp. 93-134, Princeton Univ. Press, Princeton, N. J.

Holland, H. D. (2006), The oxygenation of the atmosphere and oceans, Philos. Trans. R. Soc. B, 361, 903-915, doi:10.1098/ rstb.2006.1838.

Karhu, J. A., and H. D. Holland (1996), Carbon isotopes and the rise of atmospheric oxygen, Geology, 24, 867-870, doi:10.1130/0091-7613(1996)024<0867:CIATRO $>2.3$. $\mathrm{CO} ; 2$.

Kirschvink, J. L., E. J. Gaidoes, L. E. Bertani, N. J. Beukes, J. Gutzmer, L. N. Maepa, and R. E. Steinberger (2000), The Paleoproterozoic snowball Earth: Extreme climatic and geochemical global change and its biological consequences, Proc. Natl. Acad. Sci. U. S. A., 97, 1400-1405, doi:10.1073/pnas.97.4.1400.

Kohonen, J., and J. Marmo (1992), Proterozoic lithostratigraphy and sedimentation of Sariola and Jatuli-type rocks in the Nunnanlahti-Koli-Kaltimo area, eastern Finland; Implications for regional basin evolution models, Bull. Geol. Surv. Finl., 364, 7-67.

Long, D. G. F., G. M. Young, R. H. Rainbird, and C. M. Fedo (1999), Actualistic and non-actualistic Precambrian sedimentary styles: Examples from the Proterozoic, north shore of Lake Huron, in Proceedings of the Joint Annual Meeting of Geological Association of Canada-Mineralogical Association of Canada, Field Trip B5 Guidebook, pp. 1-50, Geol. Assoc. of Can., Toronto, Ont.

Marmo, J., J. Kohonen, O. Sarapää, and O. Äikäs (1988), Sedimentology and stratigraphy of the lower Proterozoic 
Sariola and Jatuli groups in the Koli-Kaltimo area, eastern Finland, Spec. Pap. Geol. Surv. Finl., 5, 11-28.

McLennan, S. M., A. Simonetti, and S. L. Goldstein (2000), $\mathrm{Nd}$ and $\mathrm{Pb}$ isotopic evidence for provenance and postdepositional alteration of the Paleoproterozoic Huronian Supergroup, Canada, Precambrian Res., 102, 263-278, doi:10.1016/S0301-9268(00)00070-X.

Nagashima, K. (2005), Reconstruction of millennial-scale variation in eolian dust transport path to the Japan Sea based on grain size and ESR analyses, Ph.D. thesis, 153 pp., Univ. of Tokyo, Japan.

Ogawa, N. O., T. Nagata, H. Kitazato, and N. Ohkouchi (2010), Ultra sensitive elemental analyzer/isotope ratio mass spectrometer for stable nitrogen and carbon isotopic analyses, in Earth, Life and Isotopes, edited by N. Ohkouchi, I. Tayasu, and K. Koba, pp. 339-353, Kyoto Univ. Press, Kyoto, Japan.

Ohkouchi, N., Y. Nakajima, H. Okada, N. O. Ogawa, H. Suga, K. Oguri, and H. Kitazato (2005), Biogeochemical processes in the saline meromitic Lake Kaiike: Implications from carbon and nitrogen isotopic compositions of photosynthetic pigments, Environ. Microbiol., 7, 1009-1016, doi:10.1111/ j.1462-2920.2005.00772.x.

Ojakangas, R. W. (1988), Glaciation: An uncommon megaevent as a key to intracontinental and intercontinental correlation of Early Proterozoic basin fill, North America and Baltic cratons, in New Perspectives in Basin Analysis, edited by K. L. Kleinspehn and C. Paola, pp. 431-444, Springer, Berlin.

Ojakangas, R. W., J. S. Marmo, and K. I. Heiskanen (2001a), Basin evolution of the Paleoproterozoic Karelian Supergroup of the Fennoscandian (Baltic) Shield, Sediment. Geol., 141-142, 255-285, doi:10.1016/S0037-0738(01)00079-3.

Ojakangas, R. W., G. B. Morey, and D. L. Southwick (2001b), Paleoproterozoic basin development and sedimentation in the Lake Superior region, North America, Sediment. Geol., 141-142, 319-341, doi:10.1016/S0037-0738(01)00081-1.

Papineau, D., S. J. Mojzsis, and A. K. Schmitt (2007), Multiple sulfur isotopes from Paleoproterozoic Huronian interglacial sediments and the rise of atmospheric oxygen, Earth Planet. Sci. Lett., 255, 188-212.

Pavlov, A. A., M. T. Hurtgen, J. F. Kasting, and M. A. Arthur (2003), Methane-rich Proterozoic atmosphere?, Geology, 31,
87-90, doi:10.1130/0091-7613(2003)031<0087:MRPA> 2.0.CO;2.

Rainbird, R. H., and J. A. Donaldson (1988), Nonglaciogenic deltaic deposits in the early Proterozoic Gowganda Formation, Cobalt Basin, Canada, Can. J. Earth Sci., 25, 710-724.

Rasmussen, B., I. R. Fletcher, J. J. Brocks, and M. R. Kilburn (2008), Reassessing the first appearance of eukaryotes and cyanobacteria, Nature, 455, 1101-1104, doi:10.1038/ nature 07381.

Schoell, M., and F. Wellmer (1981), Anomalous ${ }^{13} \mathrm{C}$ depletion in early Precambrian graphites from Superior Province, Canada, Nature, 290, 696-699, doi:10.1038/290696a0.

Vallini, D. A., W. F. Cannon, and K. J. Schulz (2006), Age constraints for Paleoproterozoic glaciation in the Lake Superior Region: Detrital zircon and hydrothermal xenotime ages for the Chocolay Group, Marquette Range Supergroup, Can. J. Earth Sci., 43, 571-591, doi:10.1139/E06-010.

Young, G. M. (1991), Stratigraphy, sedimentology and tectonic setting of the Huronian Supergroup, in Geological Association of Canada-Mineralogical Association of Canada-Society of Economic Geologists, Joint Annual Meeting, Field Trip Guidebook, pp. 1-34, Geol. Assoc. of Can., Toronto, Ont.

Young, G. M. (2004), Earth's earliest extensive glaciations: Tectonic setting and stratigraphic context of Paleoproterozoic glaciogenic deposits, in The Extreme Proterozoic: Geology, Geochemistry, and Climate, Geophys. Monogr. Ser., vol. 146, edited by G. Jenkins et al., pp. 161-181, AGU, Washington, D. C.

Young, G. M., D. G. F. Long, C. M. Fedo, and H. W. Nesbitt (2001), Paleoproterozoic Huronian basin: Product of a Wilson cycle punctuated by glaciations and a meteorite impact, Sediment. Geol., 141-142, 233-254, doi:10.1016/ S0037-0738(01)00076-8.

Young, G. M., C. S. J. Shaw, and C. M. Fedo (2004), New evidence favoring an endogenic origin for supposed impact breccias in Huronian (Paleoproterozoic) sedimentary rocks, Precambrian. Res., 133, 63-74, doi:10.1016/j.precamres. 2004.03.013. 